\title{
Composition of Volatile Oil of Iris pallida Lam. from Ukraine
}

\author{
Iris pallida Lam’ın Uçucu Yağı Bileşimi Ukrayna
}

\author{
(1) Olga MYKHAILENKO \\ National University of Pharmacy, Department of Botany, Kharkiv, Ukraine
}

\begin{abstract}
Objectives: To qualitatively and quantitatively study the composition of essential oil from the dried rhizomes and leaves of Iris pallida Lam. from Ukraine for the first time.

Materials and Methods: Essential oils obtained by steam distillation were investigated using gas chromatography-mass spectrometry.

Results: The essential oils were obtained from the leaves and rhizomes by yielding $0.03 \%$ and $0.20 \%$, respectively. The analysis of the oil resulted in the identification of 26 components in the leaves and 18 components in the rhizomes. The dominant terpenes in the essential oil of the leaves of $I$. pallida were squalene (6\%), hexahydrofarnesylacetone (8\%) and neophytadiene (up to 6\%). Among them, myristic acid (56\%), capric acid (14.50\%), lauric acid (15.42\%), $\alpha$-irone (2.85\%) were found as the dominant compounds of the essential oil of the rhizomes of $I$. pallida. $\alpha$-irone and $\gamma$-irone contents are accepted as the most significant criteria of the commercial quality of Iris essential oil. The compounds $\beta$-damascenone and squalene were identified for the first time in plants of the genus Iris.

Conclusion: I. pallida of Ukraine can be recommended as an additional source of raw materials for essential oil from the rhizomes and as a source of bioactive substances.
\end{abstract}

Key words: Iris pallida, essential oil, rhizomes, leaves, gas chromatography-mass spectrometry analysis

öz

Amaç: Iris pallida Lam kurutulmuş rizom ve yapraklarından elde edilen esansiyel yağın nitel ve nicel bileşimi Ukrayna'dan ilk kez okundu.

Gereç ve Yöntemler: Buhar distilasyonuyla elde edilen uçucu yağlar, gaz kromatografisi-kütle spektrometresi ile araştırıldı.

Bulgular: Uçucu yağlar, sırasıyla \%0.03 ve \%0.20 verimle yapraklardan ve köksüzlerden elde edildi. Yağ analizleri yapraklarda 26 bileşen ve rizomlarda 18 bileşenin tanımlanmasına neden oldu. I. pallida yapraklarının uçucu yağdaki baskın terpenler skualen (\%6), hekzahidrofarnesilaseton (\%8) ve neofitadien (\%6'ya kadar) idi. I. pallida rizomlarının temel yağlarının baskın bileşikleri arasında miristik asit (\%56), kaprik asit (\%14.50), lorik asit (\%15.42) ve $\alpha$-irone (\%2.85) bulunmuştur. İris esansiyel yağının ticari kalitesinin en önemli kriteri olarak $\alpha$-irone ve $\gamma$-irone içeriği kabul edilmektedir. $\beta$-Damaskenon, skualen gibi bileșikler, ilk kez Iris cinsindeki bitkilerde tanımlandı.

Sonuç: Ukrayna I. pallida'nın florası, rizomlardan esansiyel yağ için ham maddelerin ek bir kaynağı olarak ve biyoaktif maddeler kaynağı olarak tavsiye edilebilir.

Anahtar kelimeler: Iris pallida, uçucu yağ, rizomlar, yapraklar, gaz kromatografisi-kütle spektrometresi analizi

\section{INTRODUCTION}

Iris L. is the largest and the most complicated genus of the Iridaceae. The genus includes more than 300 Iris species. The range of the genus now extends to all continents of the northern hemisphere, their distribution covers Europe, the Middle East, and northern Africa, Asia, and across North America., ${ }^{12}$ Irises are used in traditional medicine and aromatherapy, and many of them are common ornamental plants. ${ }^{3}$ Sixteen species of Iris genus inhabit Ukraine. ${ }^{4}$

Some species of this genus, such as Iris versicolor L., Iris variegate L., Iris florentina L., and Iris germanica L. have gained great attention from cosmetic and perfume industries ${ }^{5,6}$ due to their violet-like smell caused by irone-type compounds. The essential oil of Iris is included in perfumes and lotions of

*Correspondence: E-mail: zolya85@gmail.com, Phone: +38572656829 ORCID-ID: orcid.org/0000-0003-3822-8409 
higher quality, such as "Iris Ganach" (Guerlain), "Extravagance d'Amarige" (Givenchy), "Dia pour Femme" (Amouage), "Les Exclusifs de Chanel 28 La Pausa" (Chanel), "Ghost summer breeze" (Ghost), and others.

There are several medicines and dietary supplements on the pharmaceutical market that are based on the presented Irises. Rhizomes of Iris pseudacorus L. are used as part of the collecting on M.N. Zdrenko (Ukraine; Russian Federation) and "Pancreophile" ("Fytolynyya SmartMed”, Ukraine)7,8, also, I. versicolor is included in homeopathic medicines "Iris-plus" (Doctor N, Russian Federation) ${ }^{9}$ and «Kaliris - ЕДАС-114» (ЕDAC holding company, Russian Federation), which are used for the treatment of papillomatosis of the bladder, chronic pancreatitis, anti-acid gastritis, and peptic ulcers of the stomach. In addition, the rhizomes of 1 . versicolor make up part of the complex drug Mastodynon (Bionorica SE, Germany), which is used for violations of the menstrual cycle, mastopathy, and premenstrual syndrome.10 "Orris (Iris) Herbasol Extract PG" was created based on the rhizome of Iris pallida (Lipoid Cosmetic, Switzerland) for use in cosmetology for skin and hair." Rhizomes of I. germanica make up part of the general tonic drug "Original grosser Bittner balsam" (Richard Bittner AG, Austria).12 Therapeutic and prophylactic drugs were created from the leaves of Iris lacteal for patients cancer such as "Vitonk" (multivitamin product) and "Laktir" (to reduce adverse effects during chemotherapy and radiation sickness) (Russian Federation).,13

Iris species have an immense medicinal importance and are used in the treatment of cancer, inflammation, and bacterial and viral infections. Numerous scientific papers on their use in treatment were published covering a variety of their pharmacologic activities, and the presence of flavones, flavone C-glycosides ${ }^{14,15}$, isoflavones, terpenoids, xanthones, or simple phenolics, stilbenes and quinones in their extracts were demonstrated within recent years. ${ }^{16,17}$

Many kinds of Irises have been valued for their medicinal properties in traditional use, especially in India ${ }^{18}$ and China ${ }^{14,19}$, where more than 30 species have been used in folk herbal medicines. Irises were reported to have various biologic properties, including having potent antiulcer, anticancer, antioxidant, piscicidal activities ${ }^{15,18}$, and cytotoxic, antiinflammatory, and antibacterial activity. 14,17,20-22

Continuing the study of the component composition of the essential oil of Iris plants ${ }^{23-29}$, we chose I. pallida Lam. as the subject of the study. "Orris root" (I. pallida, I. germanica, I. florentina) is used to obtain the essential oil in Mediterranean countries. 6,21,22,30

I. pallida is a perennial herb, the rhizome is creeping and thick. Its leaves are broadly-ensiform, $30-60 \mathrm{~cm}$ long, the perianth is pale-purple with a yellow beard. Rhizomes contain isoflavonesirigenin, iristectorigenin A, nigricin, nigricanin, irisflorentin, iriskumaonin methyl ether, irilone, iriflogenin, and others. ${ }^{14,15,17,21}$ The essential oil (about 0.1\%), known as "Orris butter", consists of about $85 \%$ myristic acid, with irone (odiferous constituent with violet-like odor), $\gamma$-dihydro-irones, ionone, methyl myristate ${ }^{22,30}$, and other substances such as fat, resin, starch, mucilage, bitter principle, glycoside-iridin, and small amount of tannin.11,17 The essential oil of the rhizome strengthens the immune system, and has a regenerating effect. ${ }^{6}$ The extract of the roots of $I$. pallida was formerly used as a diuretic, expectorant, remedy for coughs, and chronic diarrhea.18,21 The chemical composition of the essential oil of $I$. pallida from Ukraine is lacking. Studying the chemical composition of I. pallida is interesting in terms of increasing the harvesting of raw base materials.

The objective of the present work was to determine the component composition of the essential oil of the rhizomes and leaves of I. pallida from Ukraine using chromatography-mass spectrometry.

\section{MATERIALS AND METHODS}

\section{Plant material}

The subjects of the study were rhizomes and leaves of I. pallida Lam. (Iridaceae) (Figure 3), that were prepared in September, 2015, in the Luhansk region (village Kremennaya, Ukraine). Analysis and estimation of the results were performed with air-dried raw materials. Voucher specimens were deposited in the Herbarium of the Pharmacognosy Department and Botany Department in The National University of Pharmacy, Kharkiv, Ukraine.

\section{Preparation of volatile oils and extracts}

The essential oil of the rhizomes and leaves of I. pallida was obtained by steam distillation for 12 hours in an apparatus consisting of a $25-\mathrm{mL}$ round-bottomed flask, a reflux condenser, and a water bath. The method allows isolation of the essential oil from the plant material with trace quantities of essential oil. ${ }^{23,31,32}$ A weighed sample of material $(0.5 \mathrm{~g})$ was placed in a 20.0$\mathrm{mL}$ vial. The internal standard tridecane was added in terms of $50 \mu \mathrm{g}$ of the substance per a certain quantity of a plant sample. Tem milliliters of water were added to the sample and volatile compounds were distilled using steam for 2 hours under reflux. In the process of distillation, the volatile material was adsorbed on the inner surface of the reflux condenser. After the cooling system, the adsorbed material was washed by slow addition of $3.0 \mathrm{~mL}$ of ultra-pure pentane Fluka 76869 (content of microimpurities is $1.0 \mathrm{mg}$ by $1.0 \mathrm{l}$ ) in a dry vial on $10.0 \mathrm{~mL}$. Washout was concentrated by blowing $(100 \mathrm{~mL} / \mathrm{min})$ high-purity nitrogen until the volume of extract was $10.0 \mu \mathrm{L}$, and which was fully collected using a chromatographic syringe. ${ }^{33}$

\section{Chromatographic conditions}

The constituent composition of the rhizomes and leaves of the plant was studied using gas chromatography-mass spectrometry (GC/MS) on an Agilent Technologies 6890 with a 5973 mass-spectrometric detector. Introduction of the sample $(2.0 \mu \mathrm{L})$ into the chromatographic column was executed according to the splitless mode without stream splitting. The speed of sample introduction was $1.2 \mathrm{~mL} / \mathrm{min}$ within $0.2 \mathrm{~min}$. The chromatographic column was capillary DB-5 (30 m $\times 0.25$ $\mathrm{mm} \times 0.50 \mu \mathrm{m})$. Mobile phase: helium, gas flow rate $1.2 \mathrm{~mL} / \mathrm{min}$. The temperature of the sample introduction heater was $250^{\circ} \mathrm{C}$. The temperature-controlled chamber was programmable from 50 to $320^{\circ} \mathrm{C}$ with a rate of 4 degree $/ \mathrm{min}$. 


\section{Identification of components}

For the identification of components, data from the massspectra libraries NIST05 34,35 and WILEY $2007^{36}$ with a total number of spectra of more than 470.000 were used, combined with the identification programs AMDIS and NIST.

The method was used for quantitative calculations of the internal standard. ${ }^{31,32,37}$ The calculation of component content $\mathrm{C}$ ( $\mathrm{mg} / \mathrm{kg}$ ) was made using the following formula:

$C=P_{1} \cdot 50 \cdot 1000 / P_{2} M$

Where: $P_{1}$-peak area of tested substance; $P_{2}$-peak area of standard; $50-$ mass of internal standard $(\mu \mathrm{g})$, injected into the sample; $\mathrm{m}$-sample mass $(\mathrm{g})$. The relative component content was defined as the percentage of the total amount.

\section{RESULTS}

In our previous research work, we reported the component composition of the essential oil of several Irises from Ukraine (Iris hungarica, I. pseudacorus, Iris pseudacorus f. alba, I. versicolor, I, germanica) ${ }^{23-27}$ and Azerbaijan (Iris medwedewii, Iris carthaliniae). ${ }^{29}$ Monoterpene ketone $\alpha$-irone and triterpenoid squalene were identified in all samples. These substances can be used as markers in the chemotaxonomy and chemosystematics of plants of the genus Iris for further studies. Among the other components of the essential oil of Irises, different norterpenoids such as $\beta$-ionone-5,6-epoxide, $\beta$-ionone, trans-2,6- $\gamma$-irone, $\beta$-isometilionone, $\beta$-damascenone were defined in practically all Iris species. Among the other substances in the oil of Irises were neophytadiene, eugenol, $\alpha$-terpineol, germacrene $D$, terpinen-4-ol, hexahydrofarnesylacetone, farnesylacetone, phenylacetaldehyde, geranilasetone, 2-methoxy-4-vinylphenol. Also, Iris oil contains a large proportion of myristic acid (near 50-80\%), other fatty acids (e.g., caprylic, capric, lauric, palmitic) and their esters.

The component composition of Irises of Azerbaijan flora is considerably different, probably because $I$. medwedewii and $I$. carthaliniae are typical representatives of stony dry steppes, they grow in warmer climate, different from the steppe, marsh and forest Iris species of Ukraine flora. Sesquiterpenes $\beta$-farnesene, germacrene D, trans-caryophyllene, $\delta$-cadene, spathulenol, caryophyllene oxide, $\alpha$ - and $\beta$-cadinol, $\alpha$-copaene have been identified in both Iris species. ${ }^{29}$ Calamenene was present only in I. medwedewii, and $\alpha$ - and $\beta$-bisabolene epoxides were found only in I. carthaliniae. Therefore, the component composition of the oil of these irises is similar to the oil composition of the rhizomes of Iris nigricans of Jordan ${ }^{38}$, the rhizomes of Iris sofarana, and of the flowers of Iris kerneriana from Turkey. ${ }^{39}$

The aim of this work was to determine the component composition of the essential oil of I. pallida using chromatography-MS; $0.03 \%$ and $0.20 \%$ of the oil yield was obtained from the air-dried leaves and rhizomes of I. pallida, respectively, through steam distillation. Using GC/MS analysis, 26 compounds were found in the essential oil from the leaves and 18 compounds from rhizomes of $I$. pallida. The essential oil included terpenoids ${ }^{12}$, their oxygenated derivatives (alcohols, ketones, aldehydes,

esters), aromatic compounds ${ }^{11}$, higher hydrocarbons ${ }^{6}$, and higher acids of their esters. ${ }^{8,40}$ The constituents of the essential oil that were obtained from the rhizomes and leaves of I. pallida are shown with their percentages and relative retention indices in Table 1 and in Figure 1, 2.

\section{Table 1. Percentage chemical composition of the essential oil of} Iris pallida rhizomes and leaves

\begin{tabular}{|c|c|c|c|}
\hline Compound & RRI & Leaves & Rhizome \\
\hline Phenylacetaldehyde & 1001 & 1.72 & - \\
\hline 6-Methyl-3,5-heptadien-2-one & 1067 & 0.11 & - \\
\hline Decanal & 1174 & 0.24 & - \\
\hline Caprylic acid & 1220 & - & 1.72 \\
\hline$\alpha$-Ethylidene phenylacetaldehyde & 1221 & 0.21 & - \\
\hline Indole & 1242 & 1.55 & - \\
\hline 2-Methoxy-4-vinylphenol & 1275 & 1.50 & 0.25 \\
\hline$\beta$-Damascenone & 1334 & 0.39 & - \\
\hline 4-Isobutylphenone & 1384 & 15.08 & - \\
\hline 3-Phenylpyridine & 1400 & 0.40 & - \\
\hline Geranilacetone & 1411 & 1.16 & - \\
\hline$\beta$-Ionone 5,6-epoxide & 1435 & 0.76 & - \\
\hline$\beta$-Ionone & 1438 & 0.86 & - \\
\hline Capric acid & 1439 & - & 14.50 \\
\hline Dihydro- $\beta$-Irone & 1466 & - & 0.25 \\
\hline$\alpha$-Irone & 1493 & - & 2.85 \\
\hline trans-2,6- $\gamma$-Irone & 1498 & - & 1.22 \\
\hline Megastigmatrienone 1 & 1499 & 0.11 & - \\
\hline Megastigmatrienone 2 & 1515 & 0.52 & - \\
\hline$\beta$-Isometilionone & 1522 & - & 0.21 \\
\hline Benzophenone & 1550 & 31.84 & 1.11 \\
\hline Lauric acid & 1630 & - & 15.42 \\
\hline Tridecanoic acid & 1680 & - & 0.21 \\
\hline Myristic acid, methyl ester & 1700 & - & 0.17 \\
\hline Myristic acid & 1794 & 0.88 & 56.00 \\
\hline Hexahydro farnesyl acetone & 1802 & 8.05 & - \\
\hline Neofitadien & 1807 & 5.65 & - \\
\hline epi-Manoil oxide & 1973 & 0.84 & - \\
\hline Palmitic acid & 1983 & - & 1.13 \\
\hline Heneicosane & 2100 & - & 0.23 \\
\hline Tricosane & 2300 & 4.65 & 0.89 \\
\hline Tetracosane & 2400 & 1.76 & - \\
\hline Pentacosane & 2500 & 7.78 & 2.29 \\
\hline Heptacosane & 2700 & 4.05 & 0.59 \\
\hline Squalene & 2758 & 6.12 & 0.69 \\
\hline Nonacosane & 2800 & 3.13 & - \\
\hline Cerotic acid, methyl ester & 2815 & 0.64 & - \\
\hline
\end{tabular}


The essential oil of the leaves of I. pallida consists of alkanes (21.37\%), aromatic compounds (6.26\%), ketones (47.66\%), sesquiterpenes (10.06\%), diterpenes (5.9\%), triterpenes $(6.12 \%)$, accompanied by relatively smaller amounts of monoterpenes $(1.16 \%)$ and fatty acids $(0.88 \%)$.

The dominant terpenes in the essential oil of the leaves of $I$. pallida were squalene (6\%), hexahydrofarnesylacetone (8\%), and neophytadiene (up to 6\%). Among the other compounds of the essential oil of the leaves were $\beta$-ionone $(0.86 \%)$ and $\beta$-ionone-5,6-epoxide (0.76\%), $\beta$-damascenone $(0.39 \%)$, geranylacetone $(1.16 \%)$, epi-maloiloxide $(0.84 \%)$, ketones megastigmatrienone-1 (0.11\%), and megastigmatrienone-2 (0.52\%), 4-isobutylacetophenone (15.08\%).

The major components of the essential oil of $I$. pallida rhizomes were fatty acids (89\%), alkanes (8.29\%), aromatic compounds (1.36\%), sesquiterpenes (4.53\%), and triterpenes $(0.69 \%)$; monoterpenes and diterpenes were not found. The main saturated aliphatic mono-carboxylic acids were caprylic (1.72\%), capric $(14.50 \%)$, lauric $(15.42 \%)$, tridecanoic $(0.21 \%)$, palmitic (1.13\%), and myristic (56\%) acids. Among the sesquiterpenes were $\alpha$-irone (2.85\%), dihydro- $\beta$-irone $(0.25 \%)$, trans-2,6$\gamma$-irone $(1.22 \%)$, and $\beta$-isometilionone $(0.21 \%)$. Triterpenoids were represented only by squalene.

\section{DISCUSSION}

I. pallida Lam. (Figure 3) of the Ukrainian flora was chosen for the study, it had a sufficient resource base.

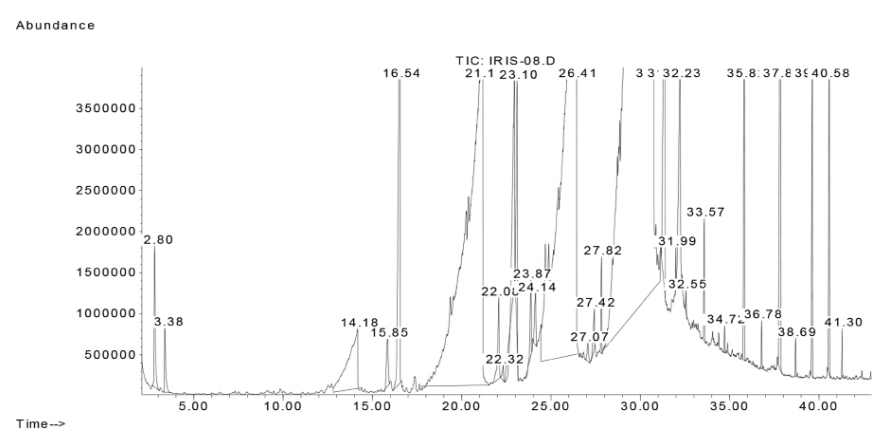

Figure 1. Chromatograms of GC-MS analysis of essential oil of rhizomes of Iris pallida

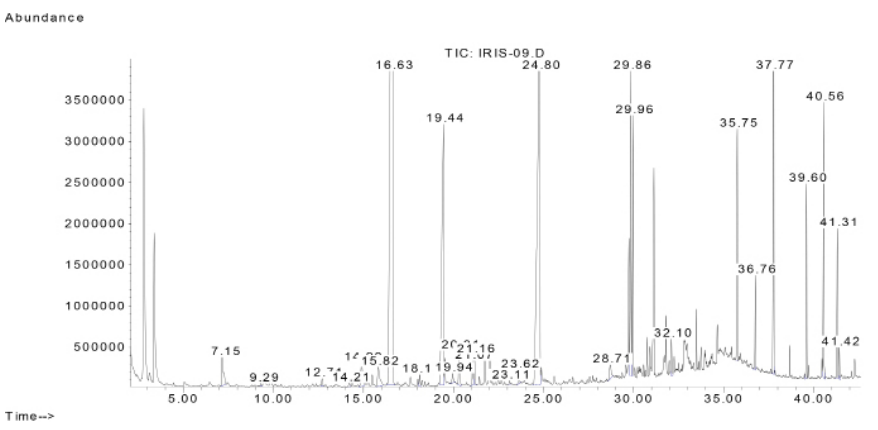

Figure 2. Chromatograms of GC-MS analysis of essential oil of leaves of Iris pallida
According to the classification of Rodionenko² (1987), I. pallida belongs to the group of Bearded Irises (Barbatae are the species with flowers, bearing a beard of multicellular hairsprings on the outer perianth lobes) from the Iris section of the series Elatae Lawrence. I. pallida is not endemic for our region because it entered the territory of Ukraine through introduction. ${ }^{4}$ It is widely cultivated. 3.4

The eessential oil from "Orris roots" (I. pallida, I. florentina and $I$. germanica) ${ }^{17,22}$ is used in perfume industries ${ }^{5,6}$ and in aromatherapy.41,42 Rhizomes are harvested, dried, and aged for three to five years. During this time, fats and oils in the roots undergo degradation and oxidation, which produces many fragrant compounds that are invaluable in perfumery, whose scent is similar to violets. ${ }^{6,30,39}$ The essential oil from Irises is obtained through steam distillation. . $^{38,39,43}$ The volatile components of $I$. pallida from Ukraine were not studied.

Through GC/MS analysis of the volatile constituents of the rhizome (Figure 1), 18 components were identified, among which fatty acids and their esters predominated with caprylic $(1.72 \%)$, capric $(14.50 \%)$, lauric $(15.42 \%)$, tridecanoic $(0.21 \%)$, palmitic $(1.13 \%)$, methyl myristate $(0.17 \%)$ and myristic $(56 \%)$ acids. The oil of the leaves is shown only by myristic acids (0.88\%). Thus, it was consistent with data in the literature, which noted that myristic acid was the major compound (and/or always present) in the Iris species.17,22-24,29 Fatty acids are known to have antioxidant, antifungal, anti-inflammatory, and immunomodulatory properties ${ }^{43}$, they are involved in metabolism, positively affect digestion, and create favorable conditions for beneficial intestinal microorganisms for their life activity. ${ }^{44}$ In addition, palmitic and myristic acids are saturated fatty acids involved in the synthesis of prostaglandins and stability of cellular membranes. It has been found that lauric acid possesses antibacterial, antitumor, antimycobacterial, and antiviral activities. ${ }^{43,45}$ The composition of fatty acids and their esters gives us the possibility to investigate the use of Iris rhizome extracts for medical purposes.

The prevalence of fatty acids and their esters, as well as aliphatic hydrocarbons and their derivatives in the volatile constituents of leaves and rhizomes seems to be a common feature among the species of Iris. ${ }^{22-29,38,39,43}$
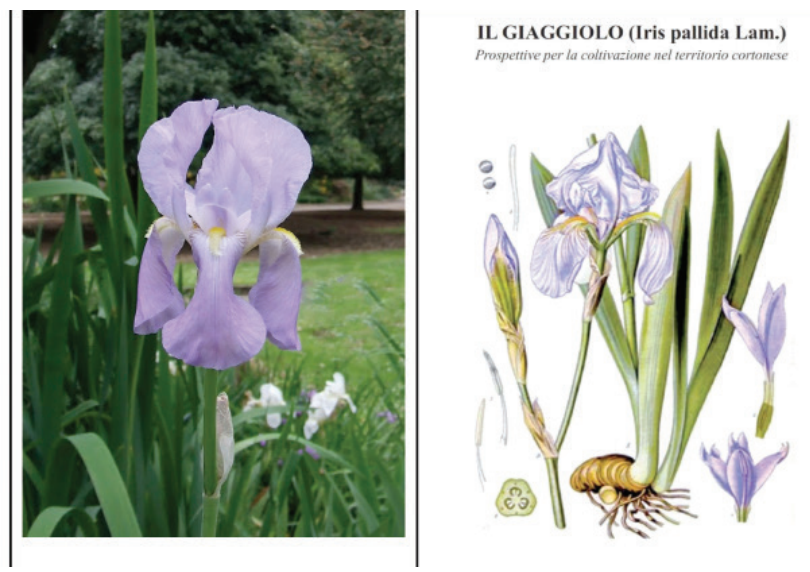

Figure 3. General view of the living plants and drawing of Iris pallida 
Monoterpenoid $\alpha$-irone was detected to make up $2.85 \%$ of the total essential oil of 1 . pallida rhizomes. It is known that ketone $\alpha$-irone is an indicator of the authenticity of iris oil. ${ }^{6}$ The presence of irones, homologues, and ionones, was reported mainly in the rhizomes of I. pallida, I. germanica, and I. florentina. ${ }^{21,30,46}$

For comparison, the essential oil of the dried rhizomes of Syrian wild $I$. germanica ${ }^{43}$ and fresh rhizomes of $I$. nigricans ${ }^{38}$ have been established to contain $\alpha$-irone at only $0.25 \%$ and $1.42 \%$, respectively, using GC/MS. In the essential oil from fresh rhizomes of $I$. florentina, $\alpha$-irone and $\gamma$-irone are absent ${ }^{46}$, but at that time, the content of $\alpha$-irone in the dry rhizome and essential oil of I. florentina were found as high (4.21\%).

In the present study, norterpenoids and their derivatives were observed in the essential oil of the leaves and rhizomes of $l$. pallida for the first time. Their compositions differed. The highest percentage of norterpenoids was obtained in the rhizomes $(9.06 \%)$ with much smaller amounts $(2.01 \%)$ in the leaves.

The largest variety of component norterpenoids was found in the oil of $I$. pallida rhizomes. $\alpha$-Dihydro- $\beta$-irone $(0.25 \%)$, trans-2,6- $\gamma$-irone (1.22\%) and $\beta$-isomethylionone (0.21\%) were identified only in the rhizome. The availability of irones and ionones in the raw material determines the characteristic smell of violets of iris and their mucolytic action. ${ }^{22}$ Various compositions of norterpenoids were found in the leaves of I. pallida. Among them, $\beta$-damascenone $(0.39 \%), \beta$-ionone (0.86\%), and $\beta$-ionone-5,6-epoxide (0.76\%) were identified.

The analysis of the essential oil of the leaves of $I$. pallida led to the identification of 26 compounds, in which the ketones benzophenone and 4-isobutylphenone constituted the major compounds, accounting for $31.84 \%$ and $15.08 \%$ of the total oil composition, respectively. Regarding the volatile constituents of the leaves, aromatic compounds, ketones, and aldehydes, together with other aliphatic hydrocarbon compounds showed a high prevalence in the total oil composition.

The highest percentage of terpenes of squalene was observed in the essential oil of the leaves of I. pallida (6.12\%), and the smallest content of squalene was in the essential oil of rhizomes $(0.69 \%)$. In addition, sesquiterpenoids hexahydrofarnesylacetone (8.05\%) and geranyl acetone (1.16\%) were detected in Iris leaves, which exhibit an antimicrobial and cytotoxic activity, according to the latest pharmacologic studies. $13,40,47$

Moreover, diterpenes neophytadiene, and epi-manoil oxide, with ketones megastigmatrienone-1, megastigmatrienone-2, 4-isobutylphenone were only indicated in the oil of the leaves and their content was 5.65, 0.84, 0.11, 0.52, and $15.08 \%$, respectively, as illustrated in Figure 2.

A high content (21.37\%) of alkanes was detected in the essential oil of Iris leaves. Its existence is caused by the fact that they are the part of the wax cuticle that covers the leaves and rhizomes of a plant, and volatile components from the raw materials are distilled off by steam, together with terpenoids.

The leaves and rhizomes of $I$. pallida contain 2-methoxy4-vinylphenol, benzophenone, squalene, myristic acid, and some saturated hydrocarbons. The chemical composition of the essential oils of the leaves of I. pallida was studied for the first time. Also, squalene and $\beta$-isometilionone were identified for the first time in the essential oil of I. pallida rhizomes. The variable composition of biologically-active compounds in the essential oil provides a basis for further study of $I$. pallida and as a promising source of raw materials for producing valuable essential oils.

\section{CONCLUSIONS}

Qualitative and quantitative analysis of the components of the essential oil of $I$. pallida from Ukraine was conducted using chromatography-MS for the first time. Rhizomes of I. pallida are characterized by the high content of essential oil $(0.20 \%)$, distinguished by a rich chemical composition. Sixteen volatile components of the essential oil of rhizomes and 26 components of the leaves were found. Dihydro- $\beta$-irone, $\alpha$-irone, trans-2,6- $\gamma$ irone, $\beta$-isometilionone, benzophenone, and others were found in the essential oil of Iris rhizomes. The dominant terpenes in the essential oil of Iris leaves were 4-isobutylphenone, benzophenone, hexahydrofarnesyl acetone, neofitadien, squalene.

Iris oil is recommended in aromatherapy for bronchial inflammation and coughing ${ }^{41,42}$, and it is used in mixtures for skin care. The essential oil of iris normalizes brain function, and has a detoxifying, diuretic, expectorant, and strengthening effect on the immune system. Phytochemical studies have shown the prospects for further pharmacologic study of iris. ${ }^{9}$ The chemical composition of biologically active substances, including the presence of irones in the rhizomes of I. pallida could have industrial significance ${ }^{6}$; irones constitute an expensive natural ingredient of the cosmetic industry. I. pallida of Ukraine flora can be recommended as an additional source of raw materials for essential oil from rhizomes.

\section{ACKNOWLEDGEMENTS}

The author would like to express their gratitude to the acting Senior Researcher, Head of Department of the Floriculture of Botanical Garden of Kharkiv National University named after V. N. Karazin, Cand. Biol. Sci. Orlova T. G. for helping in the determination of the systematic classification of the plant, and to Professor of Pharmacognosy department of National University of Pharmacy, D.Sc. in Pharmacy, Vladimir M. Kovalyov, for his advice and participation in the discussion.

Conflict of Interest: No conflict of interest was declared by the authors.

\section{REFERENCES}

1. Goldblatt P, Manning JC. The Iris family: natural history and classification. Portland; Timber Press; 2008:336.

2. Rodionenko Gl. The genus Iris L. (questions of morphology, biology evolution and systematics). London; British Iris Society; 1987:222.

3. Karpenko VP. Introduction history of species and varieties of genus Iris L. in Ukraine against the background of global trends. Umans'kiy National'nyi Universytet sadivnytstva visnyk; 2015;2:85-91. 
4. Mosyakin SL, Fedoranchuk MM. Vascular plants of Ukraine. A nomenclatural checklist, In: Mosyakin SL, ed. Kiev; 1999:346.

5. Lawless J. The illustrated encyclopedia of essential oils. Publ. Element Books Ltd; Reissue edition; 1995:256.

6. Niir Board. Modern technology of perfumes, flavours and essential oils. $2^{\text {nd }}$ ed. National Institute of Industrial Research; 2004:282-283.

7. Lekarstvennoe rastytelnoe surie. Pharmacognosy, Posobye. In:Yakovlev GP, Holynovoy KF, eds. SPb; SpetsLyt; 2004:765.

8. Medicinal preparations of Ukraine. In: Chernykh VP, Zupanets IA, eds. Kharkiv, Publishing of the NFUU; Golden Pages; 2005:512.

9. Tihomirova LI, Bazarnova NG, Mikushina IV, Dolganova ZV. Pharmacological-biochemical rationale for the practical use of some representatives of the genus iris I. (review). Rastitelnye Resursy; 2015;3:25-34.

10. Gordeeva G. Application of the drug Mastodinone with functional deviation in the reproductive system. Reproductive Health of a Woman. 2002;3:47-51.

11. Henriette's Herbal Homepage: http://www.henriettes-herb.com/ eclectic/kings/iris-vers.html

12. Patudin AV, Mishchenko VS, Nechaev NP, Kosmodemyanskiy LV. Homeopathic medicines (reference book for doctors, pharmacists and pharmacists). Moscow, Astral; 1999:252.

13. Minina SA, Pryakhina NI, Chemesova II, Chizhikov DV. A pediatric medicinal preparation containing an extract of the milk-white iris (Iris lactea). Pharm Chem J. 2008;42:37-39.

14. Wang H, Cui Y, Zhao C. Flavonoids of the genus Iris (Iridaceae). Mini Rev Med Chem. 2010;10:643-661.

15. Iwashina T, Ootani S. Flavonoids of the genus Iris; structures, distribution and function: review. Ann Tsukuba Bot Gard. 1998;17:147-183.

16. Kaššák P. Secondary metabolites of the chosen genus /ris species. Acta Univ Agric Silvic Mendelianae Brun. 2012;60:269-280.

17. Kukula-Koch W, Sieniawska E, Widelski J, Urjin O, Głowniak P, SkalickaWoźniak K. Major secondary metabolites of Iris spp. Phytochem Rev. 2015;14:51-80.

18. Khare CP. Indian medicinal plants. Heidelberg: Springer-Verlag; Berlin; 2007:836.

19. Waddick JW, Yu-tang Z. Iris of China. Portland, Oregon; Timber Press; 1992:192.

20. Zatylnikova OA, Osolodchenko TP, Kovalev VN. Antimicrobial activity of extracts of Iris pseudacorus L. Annals of Mechnikov's Institute. 2010;4:4347.

21. Roger B, Jeannot V, Fernandez X, Cerantola S, Chahboun J. Characterisation and quantification of flavonoids in Iris germanica L. and Iris pallida Lam. resinoids from Morocco. Phytochem Anal. 2012;23:450-455.

22. Deng G, Zhang X, Wang Y, Lin Y, Chen X. Chemical Composition and Antimicrobial Activity of the Essential Oil of Iris pallida Lam. Chemistry and Industry of Forest Products. 2008;28:7-12.

23. Zatylnikova OA, Kovalev VN, Kovalev SV. The study of yellow iris essential oils` components. Rastitelnye Resursy. 2013;49:233-240.

24. Kovalev VN, Mikhailenko OA, Vinogradov BA. Aromatic Compounds and Terpenoids of Iris hungarica. Chem Nat Compd. 2014;50:161-162.

25. Mykchailenko OA, Kovalyov VN, Kovalyov SV. Chromatography-mass spectrometric study of bioactive substances of rhizomes with roots of Iris pseudacorus f. alba. Farmaciya of Kazakhstan. 2015;3:38-41.

26. Mykhailenko OA. Analysis of essential oil of leaves of Iris germanica L. Science and Practice 2015: abstracts of the $6^{\text {th }}$ International Pharmaceutical Conference (November 5-6 ${ }^{\text {th }}, 2015$ ). Kaunas Lithuania. 2015;30-31. Available from: http://botanika.vdu.lt/wp-content/ uploads/2015/11/konferencijos-med\%C5\%BEiagoje.pdf
27. Mykhailenko OA, Kovalev VN. Chemical composition of essential oil from leaves of Iris versicolor. $6^{\text {th }}$ International Symposium on the Chemistry of Natural Compounds (November 21-23 $3^{\text {th }}, 2013$ ). Tashkent-Bukhara, Republic of Uzbekistan. 2013;280. Available from: https://drive.google. com/file/d/10XqiXqrVKacT8V24739wcuBgKIJVOQxq/viewhttp://www. academia.edu/25814098/ACETYLCHOLINESTERASE_INHIBITING_ CHARACTERS_OF_Salvia_spp

28. Mykhailenko OA, Kovalev VN. Aromatic compounds and terpenoids of essential oil of several Iris species. IV International Scientific Conference of Young Researchers (April 29-30th, 2016). Azerbaijan, Baku. 2016;1:187-188. Available from: http://www.academia edu / $25636164 / \%$ C 4\%B OCT \% C 4 \% B O M A \% C 4\%BO_D\% C $4 \%$ B OPLOMAT\%C 4\%BOYA_M \% C 3\% 9 CAS\%C 4\%BOR_D\%C 4\% BOPLOMAT\%C4\%BOYANIN_FORMASI_K\%C4\%BOM\%C4\%BO_pp._784-786

29. Isaev DI, Mikhailenko OA, Gurbanov GM, Kovalev VN. Constituents of Essential Oils from Azerbaijan Iris medwedewii and I. carthaliniae Rhizomes. Chem Nat Compd. 2016;52:748-750.

30. Bicchi C, Rubiolo P, Rovida C. Analysis of constituents of Iris rhizomes. Part II. Simultaneous SFE of irones and iridals from Iris pallida L. rhizomes. Flavour Fragr J. 1993;8:261-267.

31. Chernogorod LB, Vinogradov BA. Essential oils of some Achillea L. species, containing fragranol. Rastit. Resur. 2006;42:61-68.

32. Golembiovska O, Tsurkan A, Vynogradov B. Components of Prunella vulgaris L. Grown in Ukraine. J Pharmacogn Phytochem. 2014;2:140-146.

33. Bicchi C, Brunelli C, Cordero C, Rubiolo P, Galli M, Sironi A. Direct resistively heated column gas chromatography (Ultrafast module-GC) for high-speed analysis of essential oils of differing complexities. J Chromatogr A. 2004;1024:195-207.

34. NIST Mass Spec Data Center SES. Mass Spectra, 6th ed. National Institute of Standards and Technology; Gaithersburg MD; 2005.

35. NIST Mass Spec Data Center SES. Retention Indices, 6th ed. National Institute of Standards and Technology; Gaithersburg MD; 2005.

36. WILEY 2007. Available from: http://www.wiley.com/legacy/annual_ reports/ar_2007/

37. State Pharmacopoeia of Ukraine. State Enterprise: Scientific and Expert Pharmacopoeial Centre. 1ed. Kharkov; 2001:556.

38. Al-Jaber HI. Variation in essential oil composition of Iris nigricans Dinsm. (Iridaceae) endemic to Jordan at different flowering stages. Arab J Chem. 2016;9:1190-1196.

39. Başer KHC, Demirci B, Orhan IE, Kartal M, Sekeroglu N, Sener B. Composition of Volatiles from Three Iris Species of Turkey. J of Essential Oil Rese. 2011;23:66-71.

40. Wagner H, Bladt S. Plant drug analysis. Berlin; Springer; 2001:384.

41. Nikolaevskii VV. Aromatherapy. Guide. Moscow; Meditsina; 2000:336.

42. Fischer-Rizzi S. Complete aromatherapy handbook: essential oils for radiant health. Sterling publishing company, Inc; USA; 1990:240.

43. Almaarri K, Abou Zedan TA, Albatal N. Chemical analysis of essential oils of some Syrian wild Iris species. Am J Biochem Mol Biol. 2013;3:38-49.

44. Gunstone FD. Fatty acids and lipid chemistry. London; Blackie Academic and Professional; 1996:547.

45. Plant lipids: biology, utilization and manipulation. In: Denis J, ed. Murphy. Wiley-Blackwell; 2005:403.

46. Kara N, Baydar H. Scent components in essential oil, resinoids and absolute of iris (Iris florentina L). Anadolu Tarım Bilim Derg. 2014;29:70-74.

47. Wren RC. Potter's New Cyclopaedia of Botanical Drugs and Preparations. London; C.W. Daniel Company Ltd; 1988:384. 